\title{
A Importância de Moisés: Ponto de Encontro da Cultura, do Judaísmo e da Psicanálise*
}

\author{
Aline Vieira Fridman* \\ Universidade Federal do Rio de Janeiro, Rio de Janeiro, RJ, Brasil
}

\begin{abstract}
RESUMO
O artigo discute o papel de Moisés no Judaísmo à luz da reconstrução histórica de Freud (1939/2004) e de suas análises da força e permanência desta cultura e de sua tradição. Com esse personagem articulador, Freud elabora sua teoria da tradição e da transmissão, afirmando e forjando seu edifício conceitual, sobre os fenômenos sociais, em analogia com suas observações das psicanálises (individuais) que conduziu. Cotejando a versão freudiana, a versão exegética (Sellin, 1922, citado em Freud, 1939/2004), e a versão da Torá desse legislador, e tomando contradições e inconsistências pululantes na jornada do grande profeta, o artigo procura mostrar como desse personagem e de seu acontecer-histórico (die Geschichte) se derivam importantes consequências para a história primordial (die Urgeschichte) da cultura, dos monoteísmos e da própria clínica da subjetividade.
\end{abstract}

Palavras-chave: Moisés; cultura; Psicanálise; Judaísmo; transmissão.

\section{ABSTRACT \\ Moses: Bridging the Fields of Culture, Judaism and Psychoanalysis}

The author discusses Moses' role in Judaism in the light of Freud's historical reconstruction (1939/2004) and his analysis with respect to the power and resilience of this culture and tradition. Based on the mythical role of this central character, Freud's theory on tradition and transmission extends its array of interest to include the social and the clinical psychoanalytic phenomena. In a strict dialog between the Freudian, the exegetic (Sellin, 1922, cited in Freud, 1939/2004) and the overt Torah (Pentateuc) versions of Moses' narrative, while confronting its contradictions and other many inconsistencies, the author demonstrate the path from Moses and his historical-enactment (die Geschichte) to the relevant consequences to the primordial history (die Urgeschichte) of the culture, the monotheisms and the clinic of the subjectivity.

Keywords: culture; psychoanalysis; Judaism; transmission.

\section{INTRODUÇÃO}

Nosso artigo se propõe a demarcar o lugar e a importância de Moisés, uma controversa figura que exerceu grande fascínio sobre Freud ${ }^{1}$. O melhor exemplo dessa marcante (Merkwürdige) e apaixonada impressão causada em nosso autor pelas representações do personagem bíblico, se encontra em Der Mann Moses und die monotheistische Religion. Drei Abhandlungen. Nele, Freud (1939[1934-1938]/2004) escreveu os passos investigativos que o levaram a identificar desencontros entre o Moisés romantizado pela Torá $^{2}$, e exaltado pela história judaica, e o seu próprio Moisés, sobre a qual não há certezas se "foi uma personalidade histórica ou uma criação da saga" (Freud, 1939/2004, p. 7).

Para encaminhar sua empresa, Freud (1939/2004) opera ainda sobre a literatura profética e extrabíblica, e sobre fontes historiográficas documentais, apresentando ao leitor seus historiadores, seus especialistas preferidos no meio científico da época (Meyer, 1906; Sellin, 1922; Breasted, 1934 citados em Freud, 1939/2004). Como não poderia deixar de fazê-lo, Freud não esquece as versões das sagas e narrativas 
míticas sejam elas judaicas, cristãs ou laicas, já que lidou com o mito como se fosse um acréscimo à história (1939/2004). Sediando sua ousada discussão sobre o cunho fantasístico e inventivo (erdicht) dos mitos, mas tratando essa lógica com a mesma consideração exigida pelas hipóteses e a escrita científicas, Freud visa a uma verdadeira reconstrução das origens de Moisés.

Chama assim o seu alvo de "mito" (Freud, 1939/2004, p. 7) e de "estudo puramente histórico" (p. 51) tratando-o como "um caso de atuar \{agieren $\}$ em lugar de recordar" (Freud, 1939/2004, p. 85) um parricídio anterior contra o chefe da horda primitiva, tal como bem demonstrara em Tótem y Tabú (Freud, 1913/2004) ${ }^{3}$. Com isso, Freud (1939/2004) pretendia inteligir as razões para a sobrevivência dos judeus e a sólida unidade e identidade de suas tradições, e ainda por consequência direta, justificar o antissemitismo acachapante que varria a Europa, inclusive sua Viena ${ }^{4}$.

Freud $(1930,1938 / 2004)$ localiza na essência do antissemitismo o reconhecimento e simultaneamente a negação das evidências históricas (Freud, 1939/2004, p. 87; Freud, $1938 / 2004$, p. 294) da superioridade judaica nas atividades intelectuais, comerciais e jurídicas. Observemos com atenção que Freud (1939/ 2004) considera não haver traços étnicos ou culturais específicos que definam a identidade judaica "pois não são uns asiáticos de raça estrangeira, [...] mas [...] a mescla dos povos mediterrâneos e os herdeiros de sua cultura" (Freud, 1939/2004, p. 87). Segundo ele (Freud, 1939/2004), o judeu é uma resultante da sua própria história como povo determinado pela mistura de tradições dos diversos países em que viveu. Sob a permanente ameaça de pogroms $^{5}$, desde o cativeiro em Goshem, os judeus fizeram das adversidades o veículo que fortaleceu seus laços comunitários e éticos, e resistiram pela força de sua tradição ${ }^{6}$ (Freud, 1939/2004; Goldberg \& Rayner, 1987).

Embora ressalte que as razões mais irrisórias são as que mais despertam a animosidade entre os povos, no caso dos judeus, Freud (1939/2004) aposta que tal hostilidade tem uma natureza especial e se enraíza em "motivos mais profundos" (p. 88) que exercem seus efeitos desde o "inconsciente dos povos" (p. 88), determinando-se pela imposição do Cristianismo às demais culturas. Como o berço dessa religião é o Judaísmo, os outros grupos (e as gerações de descendentes) que sofreram tal imposição, sob pena de persegui- ção e morte, inconscientemente jamais superaram a coação religiosa, apenas transferiram o objeto de seu ódio para os judeus (Freud, 1939/2004).

Podemos afirmar que ao retomar aspectos históricos e políticos, Freud (1939/2004) intentava, em seu romance sobre Moisés, refletir sobre a especificidade dessa diferença que o judeu encarnava para a ideologia nazista. Pois a maximização do antissemitismo sob as diretrizes nazistas se originava numa diferença especial que supera "o narcisismo das pequenas diferenças" (Freud, 1930/2004, p. 111) este que satisfaz a "inclinação agressiva por intermédio da qual é facilitada a coesão dos membros da comunidade" (p. 111) e que parece embasar rixas entre, por exemplo, portugueses e espanhóis. Ainda que Freud relembre a atitude de repúdio do nazismo frente ao Judaísmo e ao Cristianismo, é inegável para ele (Freud, 1938/2004), e sobretudo para os argumentos históricos (Goldberg \& Rayner, 1987), que algo nos judeus excede por completo a questão religiosa e suas motivações inconscientes, e esse algo o nazismo quis abater e extinguir até o último lastro. $\mathrm{E}$ esse fator, Freud (1939/2004) não soube explicá-lo ou não considerou propício o momento para fazê-lo, deixando tal discussão em aberto sem fornecer como resposta senão uma especulação que admitiu não ser muito satisfatória ${ }^{7}$ para seus interlocutores. Maiores delongas no tema, portanto, nos afastariam da necessidade de investigar a relevância clínica das inovações conceituais que decorrem da reconstrução histórica da força e do caráter da transmissão no Judaísmo (Freud, 1939/2004).

Ao interrogar o acontecer-histórico (die Geschichte) da tradição judaica, Freud (1939/2004) reconhece/produz "um importante elo intuitivo" (p. 86) que explica os meandros da transmissão de seu patrimônio e o porquê de sua sobrevivência e de sua vivacidade. Somos então conduzidos a reconhecer que o Judaísmo não representou uma espécie de resgate redentor da herança familiar de Freud (1939/2004) após uma vida de ateísmo. Tampouco o recurso à religião resumiu-se a seu simples emprego como profícuo instrumento para descrever o funcionamento do sujeito numa analogia com as operações da cultura e seus fenômenos de massa.

Além da sobreposição entre processos neuróticos e fenômenos religiosos, transferindo conclusões da psicologia individual para a psicologia de massas, o ato de Freud (Harly, 2002; Lo Bianco, 2004) intervém na 
história judaica e se ampara nos conceitos psicanalíticos para elaborar uma teoria da transmissão da tradição (Winter, 2007). Se acompanharmos a persistência freudiana na busca das singularidades na gênese da herança ética judaica, poderemos reconhecer a novidade que sua interpretação traz, a saber, a de que as circunstâncias de vida (die Geschichte) de Moisés funcionam como um determinante, inconsciente, neste modelo de transmissão e de tradição que ele advoga. $\mathrm{O}$ grande homem passa a ser encarado como peça central para desvendar a pertinácia judaica e os caminhos da transmissão do legado ético-religioso mosaico. E é escoltado pela perturbação que lhe causava o ódio aos judeus que Freud (1939/2004) recompõe pormenorizadamente a constituição do monoteísmo o judaico é o seu paradigma - em analogia com a gênese da cultura ocidental e a da subjetividade humana.

\section{O Moisés de Freud: um egípcio da casta real}

Privar um povo do homem a quem honra como ao maior de seus filhos não é algo que se empreenda por gosto ou com leveza, e menos ainda quando se pertence a esse povo. Mas nenhuma sentença poderá nos mover a relegar a verdade em benefício de alguns presunçosos interesses nacionais [...]. (Freud, 1939/2004, p. 7)

Essa passagem sobrescrita é a marca do estilo rigoroso com que Freud se apropria dos informes sobre o maior profeta judaico (Melamed, M. M. \& Diesendruck, M. M., 2001). Não o fará pela via dos questionamentos que sistematizam a experiência dos rabinos e estudiosos nas yeshivot ${ }^{8}$, e que caracterizam desde o século XIV a formação da intelligentsia, e mais precisamente, da Geistigkeit ${ }^{9}$ judaica. Seu eixo se firmará na suspensão e inversão de certos acordos históricos, fixos e estruturantes, cuja contraditória era até então inconcebível (Lacan, 1970/1991).

Em seu romance histórico, Freud (1939/2004) assinala a figura de Moisés - futuro legislador e fundador do Judaísmo - na casta real do Egito de Akhenaton, o faraó que implementou o culto monoteísta ao Deus-sol Aton. Durante esse período excepcional da história egípcia, notabilizado por expansão territorial e crescimento econômico impressionantes, Moisés se deixara insuflar pela elevação espiritual pregada pela nova e refinada religião que dispensava cerimoniais e a adoração de imagens (Breasted, 1906 citado em Freud, 1939/2004).
Mas após a morte do Akhenaton herege, o politeísmo irrestrito egípcio foi restaurado, e Moisés tomou para si a missão de perpetuar o elevado monoteísmo de Aton longe das terras egípcias. Como governador de uma província fronteiriça e "consciente de suas grandes capacidades, ambicioso e ativo" (Freud, 1939/ 2004, p. 27), Moisés teria se deparado com uma tribo semita imigrante, a quem escolhera para transmitir essa elevação ética. Para evitar o conflito com as diretrizes reestabelecidas após o período anárquico que sucedeu a morte do faraó, Moisés deixou o Egito, levando consigo esse pequeno grupo (Freud, 1939/ 2004). No deserto, transmitiu a seu séquito o ideário religioso de Aton e forjou com eles um padrão ético de conduta, afastado de qualquer referência a uma Sinnlichkeit ${ }^{10}$ (Freud, 1939/1991). Como seu legislador e líder espiritual, dera aos futuros judeus a marca diferenciadora da circuncisão e pretendeu com eles reavivar o monoteísmo empreendido no Egito, na transmissão de um projeto de ascensão espiritual e intelectual (die Geistigkeit).

Lançando mão da dedução feita pelo historiador Ernst Sellin (1922, citado em Freud, 1939/2004), embasada na tradição profética, Freud ${ }^{11}$ considera que Moisés fora um líder excessivamente rigoroso. Sua intransigência aliada às restrições éticas do monoteísmo teria sobrecarregado a vida dos israelitas que se insurgiram e o assassinaram, rechaçando o seu ensinamento. Para prosseguir costurando história, mitos religiosos e conjecturas com o fio-mestre da Psicanálise, Freud se apropria dessa tese e faz sua aposta.

Empregando mais uma vez a historiografia (Meyer, 1906; Gressman, 1913 citados em Freud, 1939/ 2004), Freud menciona a posterior fusão entre os judeus, libertos do jugo de Moisés, e as tribos idólatras de regiões próximas. Tal conjugação ocorreu provavelmente algumas décadas após o Êxodo, quando a tradição mosaica sofreu modificações decorrentes do acordo estabelecido entre os dois grupos. A porção nativa de Meribá-Kadesh procurou afastar o caráter estrangeiro do Deus dos levitas, colocando-o como uma força reinante, desde sempre, sobre o povo. A porção que sofreu o Êxodo, arrependida, não quis abdicar das lembranças da libertação e do antigo líder, e manteve a prática da circuncisão: o símbolo externo da fé mosaica (Freud, 1939/2004).

Se estabelecer tais teses como fato é um processo dificultado por desconexões e paradoxos, por pontos frouxos nos registros a respeito, é exatamente por esse 
viés lacunar que Freud (1939/2004) pôde recobrar, desde o princípio, a jornada de vida de Moisés, afirmando que: "Se Moisés não só deu aos judeus uma religião nova, mas também o mandamento da circuncisão, ele não era um judeu, mas um egípcio; [...] é provável que a religião mosaica tenha sido [...] a de Aton, com a qual de fato coincide em alguns pontos importantes a posterior religião judaica" (Freud, 1939/ 2004, p. 27).

Sem poder se certificar da razoabilidade ou da conveniência científica de sua conceituação, é pelos fatos deduzidos por E. Meyer ${ }^{12}$ (1905, citado em Freud, 1939/2004), e por E. Sellin (1922 citado em Freud, 1939/2004), que Freud recupera, do Judaísmo para a Psicanálise, a riqueza decisiva da ideia de Moisés ter existido e ter sido assassinado por seu séquito. Ainda que não tenha se especializado no teor dessas formulações sobre o assassinato e admita que Sellin interpretou erroneamente alguns trechos proféticos, Freud (1939/2004) aceita a hipótese do exegeta como um recurso, um indispensável "fóssil de referência" (p. 38). Erro crasso da historiografia ou de uma exegese ficcional, a morte de Moisés é empregada por Freud, em sua releitura da gênese do monoteísmo, como uma ficção imprescindível que tem, para a Psicanálise, o valor de um trauma.

Mesmo pouco familiarizados com a história de Moisés, é raro não reconhecermos uma estranheza nos pressupostos iniciais de Moisés y la religión monoteísta (Freud, 1939/2004), que questionam a origem e a morte até então inequívocas do herói judaico, mesclando em suas análises as fixações textuais das sagas, das escrituras e da historiografia. Freud (1939/2004) procurava no princípio das investigações do material reunido sobre Moisés manter-se numa certa proximidade com a pesquisa histórica de seu tempo, mas a versão histórica psicanalítica ganhará uma independência da historiografia, e utilizará as incoerências dos relatos fantásticos das sagas para estabelecer verossimilhanças psicológicas que não possuíam comprovação material, mas arranjavam teorias e especulações numa mesma teia argumentativa.

Ainda que imbuído desses acadêmicos exegetas e do informe do Tanach $^{13}$, Freud (1939/2004) não se satisfaz com o conhecimento existente e não se beneficia dele para lavrar o seu estudo (Lacan, 1970/1991). Essa atitude arqueológica no uso da História Oficial (die Historie) o caracteriza, antes de tudo, como um teórico que somente submergindo no Geist ${ }^{14}$ científico e cultural que o cercava pôde então ultrapassá-lo.
[...] as tradições sobre a figura de Moisés, por sua confusão, suas contradições, [...] tendenciosamente reorganizadas por [...] capas superpostas, farão abortar qualquer empenho em trazer à luz o núcleo de verdade histórica \{historisch\} [...] Eu não compartilho dessa postura desautorizadora, mas tampouco estou em condições de desprezá-la. (Freud 1939/2004, p. 15)

Visto que "certeza não se poderá alcançar [...] e os outros autores procederam da mesma maneira" (Freud, 1939/2004, p. 27) - sobretudo diante de flagrantes miscelâneas entre épocas, profetas e juízes no Tanach - Freud (1939/2004) supõe que, após o crime, houve um intervalo histórico seguido do surgimento de um novo Moisés. Mais condizente com o relato bíblico, este segundo Moisés é genro de Ythró, alto sacerdote politeísta, e destoa do humilde pastor que abandona seu lar para libertar os hebreus cativos no Egito (Melamed, M. M. \& Diesendruck, M. M., 2001). No entanto, nos detemos no corte, na ausência de precisões históricas sobre esses dois Moisés, para indagar por quê e como "é este hiato que fascina Freud e lhe apresenta um problema especial [...]" (Bernstein, 2000, p. 46): trata-se de um Merkwürdige Tatsache, um fato marcante, cujo traço faz o seu retorno. Forjando seu inventário genealógico das corrupções de nomes e eventos no emaranhado das versões de Moisés, Freud (1939/2004) defende outra trajetória, a psicanalítica, que permite conceber numa articulação histórica o retorno dos estatutos mosaicos numa geração bastante distanciada dos israelitas libertos.

Destacamos que Moisés (Freud, 1939/2004) se tornou um conjunto de valores (Winter, 2007) que representavam o passado do líder e a nova mediação entre Deus e o povo escolhido, outras formas de culto, de configurações sociais e de leis ${ }^{15}$. A figura de Moisés torna-se a resultante do colapso histórico de múltiplas características de líderes-pai, ajustadas e sobrepostas, ganhando o formato que chegou até nós (Winter, 2007).

\section{Os Moisés judaicos: o libertador hebreu e o profeta que não conheceu a terra prometida}

E Moisés era da idade de cento e vinte anos quando morreu; não se escureceu a sua vista, nem se fugiu o esplendor de seu rosto. [...] e não se levantou mais em Israel profeta algum como Moisés, a quem o Eterno aparecera cara a cara, [...]. (Melamed, M. M. \& Diesendruck, M. M., 2001, p. 610-611, Devarim [Deuteronômio], 34: 7, 10) 
No livro de Shemot ${ }^{16}$, Moisés surge pela primeira vez entre os descendentes de Jacó que viviam no Egito sob a dinastia de um faraó "que não conheceu a José" (Melamed, M. M. \& Diesendruck, M. M., 2001, p. 153). Conta-nos a Torá que era um hebreu da casa de Levi, que "era bom" 17 e ao mesmo tempo, longe de ser um herói no dia em que Deus se revela a ele, era um fugitivo da justiça egípcia.

Sobrevivente do genocídio que visava a reduzir a população hebreia em Goshem, Moisés fora adotado pela filha do faraó e educado na casa real onde viveu, até ser expulso do reinado por matar um soldado egípcio que torturava um hebreu. Sua vida anti-heróica no exílio, em Midiã, consistia em guardar o gado do sogro até o momento em que Deus lhe fala de dentro de uma sarça ardente e lhe nomeia libertador dos hebreus em cativeiro no Egito. Esse Moisés no exílio passa a ser retratado como "pesado de língua" (Melamed, M. M. \& Diesendruck, M. M., 2001, p. 161) e "incircunciso de lábios" (p. 169). Tenta declinar da ordem divina alegando sua gagueira e o esquecimento do idioma para com isso desabilitar-se de negociar com o faraó a liberdade do povo (Shemot [Êxodo], 32:1-8). De temperamento extremado, mas acompanhado pelo irmão Aarão, seu porta-voz, Moisés vai se formando como líder e intercessor nas entrevistas que tem com o faraó.

Ressaltamos em sua biografia bíblica a presença de diversas e concorrentes características que o tornam um personagem que transita entre o Moisés humanizado, assomado por limitações físicas e vontade vacilante, e o profeta que achara graças aos olhos do Deus que o orientava. Apesar de condutas imperiosas e irascíveis como legislador apaixonado na preservação do Monoteísmo ${ }^{18}$ - tendo em vista episódios como o do bezerro de ouro - seus seguidores israelitas o amaram e o admiraram até sua morte (Melamed, M. M. \& Diesendruck, M. M., 2001). Por ter nascido "bom" carregava consigo a presença divina e conseguia ver a face de Deus através de um vidro claro, por isso, a ele, e não a outro profeta, Deus teria dado a Torá.

Reconhecemos como evidência superestimada por Freud (1939/2004), a inconsistente construção bíblica e sublinhamos que a inclusão do Moisés multifacetado em seus argumentos determina a interpretação psicanalítica da tradição e das escrituras judaicas. Sem se opor aos paradoxos e às inconsistências que identifica na Torá, nessas passagens dedicadas a Moisés, Freud não os abandona, mas trabalha com eles.
Eis aqui o seu verdadeiro e inovador salto teórico: ter alinhavado a Bíblia, de onde extrai as motivações para o crime contra Moisés, com a exegese dos historiadores que defendem essa teoria, para então apresentar, com uma costura mais firme, suas demais conclusões. Estabelecendo uma cumplicidade entre a tradição religiosa e a matéria historiográfica, Freud (1939/2004) pôde derivar do Tanach e de outras fontes (Sellin, 1922; Meyer, 1905 citados em Freud, 1939/2004) causas possíveis que fomentaram no seio da exegese a teoria de uma morte violenta para Moisés (e na tradição judaica, as razões para escondê-la) e ao invés de se chocar com a versão sagrada lhe dá uma continuidade verossímil.

\section{O SALTO E A CONTINUIDADE}

Se não tivesse podido me apoiar numa interpretação analítica do mito de abandono, e passar daí para a conjectura de Sellin sobre o fim de Moisés, tudo teria tido de permanecer sem ser escrito. [...] demos agora o mergulho. (Freud, 1939/2004, p. 56)

Freud (1939/2004) relembra Sellin (1922, citado em Freud, 2004) e sua defesa de que o assassinato de Moisés fora contado no meio sacerdotal, ganhando maior consistência bem mais tarde num registro escrito, onde ele pôde interpretá-la. As consequências que Freud (1939/2004) extrai desse crime - articulando-o com outros eventos que trazem à baila a pré-história humana - é o que nos permite diferenciar seu Der Mann Moses do, como pudemos ver, não tão mitificado Moisés judaico.

Em 1970, Lacan promoveu algumas lições sobre os três mitos de Freud - Édipo, Moisés e o pai da horda primitiva -, discutindo um aspecto factual do mito de Moisés presente tanto em Freud como no estudo do biblista e arqueólogo alemão Ernst Sellin (1922 citado em Freud, 1939/2004): o assassinato de Moisés. Decantando do relato bíblico numerosas contradições na combinatória de nomes, circunstâncias e locais fixados pela historiografia documental, o procedimento de Freud (1939/2004) se mostra bastante distanciado das teses teológicas (Sellin, 1922 citado em Freud, 1939/2004). Entretanto, é um fato comum à Psicanálise e à exegese terem tido algumas de suas valiosas conclusões sobre a narrativa bíblica, as lendas e mitos judaicos, ridicularizadas com interpretações e resenhas ferozes da comunidade científica, e que não se 
limitaram à época de suas publicações (Caquot, 1970/ 1991).

Deste modo, nos apropriamos das hipóteses de Sellin (1922 citado em Caquot, 1970/1991) publicadas no livro Moses und seine Bedeutung für die israelitischjüdische Religionsgeschichte à luz dos comentários de André Caquot (1970/1991). Não analisaremos o material textual exegético em si mesmo, mas apenas a pertinência das análises de Lacan (1970/1991) e de Caquot (1970/1991) sobre as teses desse original (Sellin, 1922, citado em Lacan, 1970/1991). Mesmo que as proposições de Sellin tenham encontrado boa recepção no texto de Freud, não sugerimos uma identificação no uso que ambos fizeram da ideia do crime contra Moisés. Abordaremos esse feito no que ele permite a Freud (1939/2004) afirmar as bases de sua teoria da transmissão e nos restringimos, no trabalho do exegeta, ao seu método de interpretar excertos bíblicos restituindo ao texto evidências que estavam às margens, nas entrelinhas.

Segundo Caquot (1970/1991), a exegese equivocada e arbitrária de Sellin (1922 citado em Freud, 1939/2004) deu a Freud uma hipótese historiográfica clara e rigorosa, porém falsa. Sellin, um expert menos cético do que seus contemporâneos e banhado pela ideologia protestante, constrói um Moisés, também fundador do Judaísmo, cuja prédica moral fora seguida pelos profetas que lhe sucederam (Caquot, 1970 citado em Lacan, 1970/1991).

Asseverando que Sellin (1922) jamais afirmou que sua leitura da Bíblia concluía fatos acordados, Caquot (1970/1991) demonstra como a ideia do assassinato de Moisés tornou-se instrumento-chave para que o exegeta depreendesse outros eventos históricos. Tomado de uma "virtuosidade arbitrária" (Caquot, 1970/1991, p. 242), Sellin tentara corrigir determinados trechos do original para obter um sentido "mais satisfatório" (p. 242), isto é, foi sua a escolha metodológica de seguir pelas vias de um sentido, subjacente ao texto, e ir derivando fatos.

Guiado por suspeitas inseminadas durante a leitura de Oséias, Sellin (citado em Caquot, 1970/1991) reinterpreta uma passagem do livro Baamidbar 25 (p.4679) referente ao episódio em que um judeu é flagrado em adultério com uma moabita, e em seguida, é morto por Pinchas, para advertir e salvar o povo, através do sacrifício, da ira de Deus. O exegeta conclui que a morte desse transgressor, de nome Zimri, é uma subs- tituição do nome de Moisés e de seu assassinato (Caquot, 1970/1991), que não fora um evento qualquer e, portanto, termina por adquirir o valor de expiação pelos pecados dos israelitas. Trata-se aqui, como Freud (1939/2004) bem o sintetizou, de "outra invenção destinada a neutralizar [um] incômodo elemento de prova" (p. 43).

Tal evento teria sofrido posteriormente retificação na tradição descendente da linhagem sacerdotal: o nome de Moisés foi substituído pelo de Pinchas, assim como outros nomes - os originais? - que foram apagados para dar lugar a figuras irrisórias que, após suas transgressões, se perdem no anonimato. Outros exemplos, selecionados por Caquot (1970/1991), revelam a imaginação singular e exagerada de Sellin, mas esse é o bastante para reconhecermos seu arguto método comparativo na construção de uma historiografia assentada na desfeitura das (in) correções sagradas. Esse procedimento desconfia do tecido do texto e o interroga, pressionando suas incoerências.

\section{0 assassinato de Moisés é o retorno da Urgeschichte da cultura}

O sistema totêmico era, por assim dizer, um contrato com o pai no qual este último prometia tudo quanto a fantasia infantil tem direito de esperar dele: amparo, providência e indulgência, em troca disso, [os homens] obrigavam-se a honrar sua vida [...] não repetir com ele aquela façanha em virtude da qual havia perecido o pai verdadeiro. (Freud, 1913/2004, p. 146)

Com sua biografia de Moisés, Freud (1939/2004) revisita a insistência de seus valores éticos (espirituais/intelectuais), e forja com os conceitos psicanalíticos um tipo de transmissão que ocorre por intervalos, exigindo um período de latência para o posterior retorno de sua verdade histórica (historische Wahrheit) como ética religiosa. Se por um lado, a ratificação da teoria do assassinato do líder pelas mãos dos próprios judeus estremece e desequilibra os pilares de seu texto diante da comunidade judaica, o fortalece diante da certeza com que usa essa hipótese para sustentar a peculiaridade da transmissão, não apenas na Psicanálise, mas de todo tipo de transmissão. Freud (1939/2004) usurpa do povo judeu seu "herói nacional" (p. 7) incutindo entre a geração que conheceu a Moisés a indelével responsabilidade pelo parricídio. Mas sob outra ótica, ele afirma que a sobrevivência do Judaísmo e da sua tradição decorre necessariamente 
desse crime que arrancou Moisés do acontecerhistórico imediato, tornando-o um fragmento do passado, recalcado e esquecido, que retorna como um intransigente apelo da crença, como "verdade irresistível" (Freud, 1939/2004, p. 81), exercendo enorme pujança sobre os grupos humanos pela cicatriz traumática que deixaram na história.

Em Tótem y Tabú (Freud, 1913/2004), Freud já demonstrara a mesma obstinação ao se debruçar sobre a pré-história do contrato social em sua relação com o totemismo e com o tabu do incesto, junto às primeiras práticas exogâmicas que levaram à instituição das culturas. Assim, cercou-se de uma rede de teorias etnológicas e sociológicas sobre esses primórdios (Freud, 1913/2004), onde pinçou a hipótese do assassinato de um chefe-pai como o evento capital que reestruturou uma horda primordial, sob a chefia de "irmãos", - que só se irmanam Nachträglichkeit sob a proibição de ocuparem o antigo lugar do pai morto - e tornou-a o primeiro esboço de uma cultura: o pontapé inicial para o totemismo, as tradições e sua transmissão às gerações ulteriores.

As circunstâncias e motivações para o crime teriam inscrito a gênese da cultura, agindo como seu preâmbulo e fundando o seu real (Lacan, 1970/1991). Esses acontecimentos primordiais (die Urgeschichte), em realidade, esses assassinatos primordiais são ocasiões diferenciadas na história de um povo. O chefe de uma horda primordial e o líder espiritual dos judeus teriam deixado marcas tão sérias e inelimináveis na memória das culturas, em que estiveram, que foi preciso o seu apagamento do cenário social ou religioso para que se pudesse esquecê-los e para que suas significações retornassem em um estágio temporal póstumo sob a instauração de uma sociedade ou de uma tradição religiosa. Para Freud (1939/2004), esse retorno nachträglich explicaria também a ânsia por um Messias, bem como as religiões primordiais, como índices do arrependimento profundo pelo assassinato daquele chefe, da consciência de culpa e do desejo de devolver à vida esse pai ultrajado e sepultado.

O Moisés soterrado e esquecido terá retornado como crença religiosa inabalável, rechaçando imagens e deuses do passado, impondo-se como o monoteísmo, doravante judaico, de onde se descolará a doutrina que culmina no Cristianismo (Freud, 1939/2004). A necessidade de um povo quis fazer de Moisés um judeu que, sobressaindo-se da pré-história israelita no Egito, introduziu a elevada crença que conformaria mais tarde a identidade e a unidade do povo judeu. Eis a hipótese que Freud (1939/2004) insere na sua versão histórica do monoteísmo, dando inteligibilidade e continuidade a eventos aparentemente distanciados e de verificabilidade irrealizável - se os considerarmos sob uma ótica positivista - numa história fundada por uma verdade que não soa verossímil (Freud, 1939/ 2004, p. 17).

Por fim, "no decorrer da história judaica, a Geistigkeit exigida pelo monoteísmo mosaico acabou vitoriosa na definição do judaísmo" (Bernstein, 2000, p. 49). Vale insistir que o Moisés morto funciona como peça contumaz, um "trauma eficiente e esquecido", (Freud, 1939/2004, p. 77) porque representa, para Freud, a possibilidade de elaborar uma teoria da transmissão e da tradição fundada em pontos lacunares, mas que justifica a sobrevivência e a atração da religião monoteísta, cujo modelo tem início na proeza judaica.

\section{A analogia e a transmissão}

[...] a psicologia individual é simultaneamente a psicologia social. (Freud, 1921/2004, p. 34)

Com tais elucidações sobre a cultura e o monoteísmo, Freud (1939/2004) também esperava obter extensão teórica para sua clínica. Considerando que existe uma relação de identidade, de simultaneidade entre o social e o individual, ele cogita a influência de uma herança arcaica que não fora transmitida oralmente, mas que retornara das sombras (Freud, 1939/2004, p. 84) dentre os descendentes distantes da geração que conhecera Moisés e dos quais não se poderia esperar que soubessem algo dessa tradição há muito esquecida e abandonada. Não cogitamos explicar essa constatação de Freud (1939/2004) adentrando pela polêmica teoria de uma tradição herdada filogeneticamente ou pelo pragmatismo da tradição comunicada. Porém, não se pode ignorar a equivalência entre a clínica freudiana da cultura e a "psicanálise dos indivíduos" (Freud, 1939/2004, p. 125), já que nosso autor supõe que ocorrências históricas traumáticas na fundação e na manutenção do vigor da cultura também operam de forma análoga na constituição do sujeito, do individual.

Para uma experiência, como o parricídio primordial, poder retornar em um momento bem posterior, é preciso que tenha se dado de forma traumática e esteja ligada à sexualidade ou à agressividade. Impressões desse tipo, recalcadas, Freud (1905, 1939/2004) as 
localiza nos primeiros contatos da criança com o conhecimento sobre a sexualidade e a origem dos bebês (e a sua própria). Desse período das investigações edípicas, movida pela pulsão epistemofílica, a criança sairia frustrada, e essas questões cairiam no esquecimento (Freud, 1905/1939). Atentemos para essa abordagem freudiana da investigação infantil na qual não está em jogo a mera curiosidade do intelecto em desenvolvimento, mas as primeiras experiências com o próprio desejo, com o sexual. Essa pulsão ao saber, de saber, que comanda as atividades infantis é determinada pelo processo de constituição do desejo que culmina no abandono do investimento amoroso, incestuoso nos pais e irmãos, para encaminhar-se a objetos novos, exogâmicos.

Tendo discutido o percurso que Nachträglichkeit será visto como necessário à constituição de um povo ou de uma religião, precisamos reaver o que Freud (1939/2004) trata como uma fórmula - "trauma precoce - defesa - latência (amnésia) - irrupção da neurose - retorno do recalcado" (p. 77) - da história infantil. Nesta teorização, ele estabelece uma causa para as neuroses e o aparecimento de seus sintomas na vida adulta, procurando também descrever seus procedimentos clínicos. Neste âmbito, é situada uma lógica de causas e efeitos possibilitada pelo retorno do recalcado e do esquecido através de traços de impressões primordiais traumáticas, às quais atribui um caráter de verdade primordial e persistente: o ponto de origem do sujeito.

\section{A tradição eficiente e o impossível da transmissão}

[...] em que consiste a genuína natureza de uma tradição e sobre o quê descansa seu poder particular. (Freud, 1939/2004, p. 51)

A teoria da religião de Freud (Bernstein, 2000) justifica o transbordamento mais tardio dos ensinamentos mosaicos pelo mecanismo do retorno do recalcado (o crime contra Moisés) após um período de latência que trouxe o reavivamento de traços de acontecimentos traumáticos primordiais, afastando a intervenção das elucidações mais racionais, "o veto lógico" (Freud, 1939/2004, p. 98), e impondo uma verdade suprimida. Trata-se, para Freud (1939/2004), da transmissão inconsciente de traços de circunstâncias traumáticas, que se impõem como pontos de fixação - e de repetição - na experiência de um povo, e de igual modo nas neuroses.
Aliando o patrimônio da tradição comunicada ao estudo analítico da vida anímica infantil, Freud (1939/2004) extraiu do monoteísmo uma generalidade condizente com sua longevidade, explicada pela permanência desses restos mnêmicos inconscientes, desfigurados, nas entrelinhas dos textos sagrados e eruditos. Com sua articulação histórica, o objetivo de Freud (1939/2004) é que leiamos o Moisés "como uma interpretação que visa menos a uma realidade histórica do que a uma verdade que causa a constituição de um povo" (Harly, 2002, p. 5).

Em diversos momentos desses ensaios sobre o último profeta, Freud (1939/2004) opõe fixação escrita e tradição oral e questiona suas formas de transmissão e sua eficiência na perpetuação de um ideário ou da lembrança de um personagem político ou religioso. $\mathrm{O}$ que surpreende é que ele se desloca da oposição entre conjectural e material, e do contraste entre a informalidade fantasística e sem rigor das sagas míticas e os argumentos dos experts no assunto. Sem tramitação histórica contínua, essa tradição que não foi comunicada nem herdada por um acerto testamentário, trilhou outra via para chegar às gerações que não conheceram Moisés (Freud, 1939/2004). Ignorando as desfigurações de suas particularidades históricas, sua transmissão se deu por uma proliferação no escuro, valendo-se do esquecimento, do funcionamento do inconsciente e dos hiatos e intervalos de tempo.

\section{CONSIDERAÇÕES FINAIS}

Ousamos afirmar com Freud (1913, 1939/2004) que tais tradições exigem um período de latência para retornarem triunfantes, exercendo uma força compulsória sobre os que se farão seus herdeiros. Contra qualquer defesa de que a especificidade das hipóteses de Freud (1939/2004) estaria restrita ao Judaísmo, o que se faz notar é que em sua dedicação à figura de Moisés, ele sublinha na história judaica um evento que se repetiria partout. Ainda que tenhamos direcionado a questão para sua relação com o Judaísmo, cabe perguntarmos o que Freud (1939/2004) pretendia ao ratificar teses historiográficas que golpeavam a identidade judaica durante a ascensão nazista, quando os judeus estavam sendo deportados e submetidos à espoliação cultural e financeira. Por acaso a Shoah não acabaria com a tradição judaica, posto que essa herança seria inapagável mesmo com os extermínios em massa?

Interação Psicol., Curitiba, v. 19, n. 2, p. 295-306, maio/ago. 2015 
Constatamos que Freud elaborou um encaminhamento psicanalítico e, certamente, bastante judaico, ao mostrar que o essencial em uma tradição tão forte, isto é, o seu trauma, (o que constitui o seu real), - aquilo a partir do qual a religião judaica foi (re)edificada, (re)inventada - se transmite por meios sobre os quais não se tem controle, não se delibera. $O$ retorno desses sulcos históricos é o que explica as razões da sobrevivência de uma tradição atravessada desde sempre pela fuga dos pogroms e pela experiência, nos últimos anos de Freud, da ascensão do antissemitismo nazista.

Apostamos que a área de problemática freudiana pouco diferiu das seguintes indagações: Como se forma a identidade judaica? Numa alienação do Judaísmo dos pais é que o sujeito se torna de fato herdeiro da crença? Se o que um sujeito herda em termos de sintomas, de constituição psíquica tem relação com a forma pela qual se herda o Judaísmo - ou outra tradição ou legado familiar - das gerações anteriores, será preciso interpelar mais tanto o domínio da intelligentsia judaica quanto os psicanalistas, pois examinar a raison d'être da tradição judaica tem efeitos sobre a clínica do jour le jour.

Para Lacan (1970/1991), o essencial nessa teoria da transmissão e que é indicado por cortes, por descontinuidades e hiâncias, é a dimensão do impossível que ela comporta. Ao invés de supor uma transmissão de cunho filogenético (Freud, 1939/2004) para explicar o fascínio do Judaísmo, Lacan (1970/1991) sugere que seu efeito traumático, seja metaforizado pela remissão entre os significantes na estrutura da linguagem. Em sua leitura, marcadamente estruturalista, (1970/1991), a noção de trauma se refere à própria entrada na dimensão da linguagem, quando há a perda da dimensão natural e imediata ${ }^{19}$ dos objetos, própria à experiência dos animais, em oposição à égide do significante.

Quando falamos, estamos assujeitados ao equívoco, à não-univocidade, e ao que na psicanálise se denomina como uma autonomia do significante (Lacan 1968-9, citado em Chemama, 2009), que por definição é descolado, desvinculado do significado. O que conta é o seu peso como imagem acústica, como significância que determina o sujeito, efetivando-se à revelia do eu, mas não como palavra significada. A derrocada da significação em prol da lógica significante tem consequências psíquicas importantes, já que na cadeia remissiva que os significantes constituem, não há conti- nuidade de um elemento a outro, não há identificação ou completude na articulação entre eles. Se não há sobreposição ou equalização entre significantes, pelo significado, resta uma diferença, um intervalo em que a significação "deixa a desejar" (não satisfaz) e deixa que esse lugar seja o de uma convocação ao sujeito do desejo.

Em sua opacidade, o significante não representa a si mesmo para o outro que o sucede, e tampouco pode representar o sujeito. Essa falta de transparência significante aponta para o lugar onde o sujeito do inconsciente aparece como representante "da representação que falta" (Lacan, 1964-5, p. 596), e é o mesmo em que ele "está sufocado, apagado" (Lacan, 1968-9, p. 18). Esse sujeito barrado que se efetiva entre os significantes (S1-S2), como pura diferença, é produzido pelo corte entre as gerações como efeito do advento da cultura, dos monoteísmos e da própria linguagem sobre esse sujeito que não sabe de si, que não dispõe de identidade e de roteiros prévios sobre seu desejo e suas escolhas de vida. Por uma invenção, pela extração e pela tomada dos significantes que o constituem, que norteiam sua história, esse sujeito deverá se fazer herdeiro de um legado, que herdará à medida que o forjar, frente ao impossível de se transmitir um saber exato e invariável sobre a vida, sobre o que é o homem, sobre o sexo e a morte: temas fundamentais da vida humana que, em contrapartida, ultrapassam-na. A herança do assassinato de Moisés torna-se a injunção de inventar o que será doravante a história de cada um como judeu no mundo. Se o Judaísmo não é herdado pelo genótipo familiar, a tese de Freud (1939/2004) defende que deverá emergir um sujeito que se colocará como judeu na cadeia das gerações que o antecederam, como herdeiro da tradição de seus pais, numa contingência que depende do posicionamento ético e não dos mapas genéticos.

Não podemos precisar o quanto os judeus chegaram a tomar conhecimento da tradição mosaica e o quanto inventaram e retificaram para preencher as lacunas de tal herança (Freud, 1939/2004). Sobre esse aspecto, as certezas tropeçam, mas esse enodamento entre as gêneses do judaísmo, da cultura e do sujeito é a verdade histórica elaborada pela Psicanálise, a que é construída a cada caso, na clínica ou na cultura. Contrariamente ao mito que eleva seus protagonistas, livrando-os de uma realidade ordinária ou mesmo desagradável, a herança de Freud (1939/2004) então se nos revela como uma aposta pontual nas relações entre a 
verdade e a história como um árduo trabalho de (re)construção.

\section{REFERÊNCIAS}

Bernstein, R.J. (2000). Freud e o legado de Moisés (L. Rumchinsky, trans.). Rio de Janeiro, RJ: Imago.

Caquot, A. (1991). Exposé de M. Caquot. In Lacan, J., Le séminaire livre XVII, L'envers de la psychanalyse. Paris: les Éditions du Seuil (Trabalho original publicado em 1970).

Chemama, R. \&Vandermersch, B. (2009). Dictionnaire de la psychanalyse. Paris: Larousse in extenso.

Freud, S. (2004).Tres ensayos de teoria sexual. In J. Etcheverry (Ed. \& Trans.), Sigmund Freud Obras Completas (Vol. 7, pp. 111-222). Buenos Aires: Amorrortu Editores. (Trabalho original publicado em 1905)

Freud, S. (2004) Tótem y Tabú. In J. Etcheverry (Ed. \& Trans.), Sigmund Freud Obras Completas (Vol. 13, pp. 1-164). Buenos Aires: Amorrortu Editores. (Trabalho original publicado em 1913)

Freud, S. (2004). Psicología de las masas y análisis del yo. In J. Etcheverry (Ed. \& Trans.), Sigmund Freud Obras Completas (Vol. 18, pp. 63-136). Buenos Aires: Amorrortu Editores. (Trabalho original publicado em 1921)

Freud, S. (2004). El malestar en la cultura. In J. Etcheverry (Ed. \& Trans.), Sigmund Freud Obras Completas, (vol. 21, pp. 57-140). Buenos Aires: Amorrortu Editores. (Original publicado em 1930)

Freud, S. (2004). Comentario sobre el antissemitismo. In J. Etcheverry (Ed. \& Trans.), Sigmund Freud Obras Completas, (vol. 23, pp. 289-296). Buenos Aires: Amorrortu Editores. (Original publicado em 1938)

Freud, S. (2004). Moisés y la religión monoteísta. In J. Etcheverry (Ed. \& Trans.), Sigmund Freud Obras Completas, (vol. 23, pp. 1-132). Buenos Aires: Amorrortu Editores. (Original publicado em 1939)

Freud, S. (1991). Der Mann Moses und die Monotheistische Religion. Drei Abhandlungen. In Sigmund Freud Gesammelte Werke, Werkeaus den Jahren 1932-1939 (pp. 103-246). Frankfurt: S. Fischer. (Trabalho original publicado em 1939)
Fridman, A. V. (2012). Mito e verdade em Freud: como se constrói uma clínica. Revista Estilos da Clínica do Departamento de Psicologia da USP, Vol. 17, número 1 ISSN 1981-1624 (versão online).

Gay, P. (1989). Freud, uma vida para o nosso tempo. (D. Bottmann, Trans.). São Paulo, SP: Companhia das Letras.

Goldberg, D.J. \& Rayner, J.D. (1987). Os judeus e o judaísmo. (P. Geiger \& C.A. Oighenstein, Trans.). Rio de Janeiro, RJ: Xenon.

Harly, A. (2002). Le Moïse, un acte freudien. Bulletin de L'Association freudienne internacionale, Retirado de www.freud-lacan.com

Houaiss, A. (2005) Dicionário eletrônico da língua portuguesa. CD- Rom. Rio de Janeiro, RJ: Objetiva.

Lacan, J. (1964-5). Les problèmes cruciaux de la psychanalyse. Le séminaire XII, Retirado de www. staferla.free.fr/seminaires

Lacan, J. (1968-9). D'un autre à l'Autre. Le séminaire, livre XVI, Retirado de www.staferla.free.fr/seminaires

Lacan, J. (1991). Le maître châtré, EEdipe et Moïse et le père de la horde, La féroce ignorance de Yahvé. In $L e$ séminaire livre XVII, L'envers de la psychanalyse. Paris: Les Éditions du Seuil (Trabalho original publicado em 1970).

Lo Bianco, A. C. (2004). O ato no texto analítico: significação e autorização. Retirado de: http://www.tempofreudiano.com.br/artigos/detalhe.asp?c od=22\#_ftn

Melamed, M. M. \& Diesendruck, M. M. (2001). Torá - A lei de Moisés. São Paulo, SP: Sêfer.

Unterman, A. (1992). Dicionário judaico de lendas e tradições (P. Geiger, Trans.). Rio de Janeiro, RJ: Jorge Zahar Editor.

Winter, J. P. (2007). Sommes-nous vraiment sortis d'Égypte? Retirado de http://www.akadem.org/sommaire/ themes/philosophie/2/5/module_2707.php

\footnotetext{
Recebido em: 09/02/2014 Última modificação em: 22/07/2014 Aceite final em: 21/09/2014
}

Notas:

1 Tome-se como exemplo desse fascínio os artigos El Moisés de Miguel Angel (Freud, 1914/2004) e, aqui discutidos, os três artigos que integram o livro Moisés y la religión monoteísta (Freud, 1939/2004); sugerimos ainda a consulta da carta de 22 de abril de 1933 escrita por Freud ao amigo E. Weiss e da correspondência entre Freud e A. Zweig comentadas detidamente em Lemérer, B. (1998). Les deux Mö̈ses de Freud. Paris, France: Érès.

2 Torá é uma palavra hebraica que significa ensinamento e é sinônimo de Pentateuco e de Os Cinco livros de Moisés, a saber: Bereshit (Gênesis), Shemot (Êxodos), Vayicrá (Levítico), Bamidbar (Números) e Devarim (Deuteronômio) (Melamed, M. M. \& Diesendruck, M. M., 2001). 
3 “O destino havia aproximado o povo judeu da grande façanha e do crime atroz do tempo primordial, o parricício, dando-lhe a ocasião de repetir ele mesmo com a pessoa de Moisés, uma destacada figura paterna” (Freud, 1939/2004, p. $85)$.

4 Cf. Prefácio de James Strachey à tradução inglesa de Moisés y la religión monoteísta (Freud, 1939/2004, p. 5). Embora não tenha invadido a Áustria, tal como pretendia, assim que foi nomeado Chanceler, Hitler incitava os grupos paramilitares e os nazistas do país, além de ditar as regras do governo do chanceler Dollfuss. Em 1936, o novo chanceler austríaco fez um acordo, de cláusulas escusas, com o governo alemão comprometendo-se com uma política de não intervenção em que deveria admitir ações ilegais de partidos austríacos nazistas que foram disseminadas de forma ainda mais rápida e intensa do que na Alemanha (Gay, 1989). Houve novos boicotes das atividades econômicas dos judeus, humilhações e torturas físicas públicas, e intensa propaganda antissemita. Essas operações da política hitleriana foram apenas a continuação de intervenções que se iniciaram em 1933, simultaneamente nos territórios alemão e austríaco, inclusive em Viena (a cidade natal de Hitler cuja apropriação era uma de suas grandes ambições). Em 1934, o nome de Freud foi excluído da lista de professores membros da Universidade de Viena, onde - precisamente em sua escadaria - dois anos depois, Moritz Schlick, co-fundador do Círculo de Viena, foi assassinado por um membro do partido nazista (Gay, 1989).

No dia 12 de março de 1938, tropas nazistas invadiram a Áustria e a ocuparam (Anschluss) sob o entusiasmo da população, principalmente das facções extremistas que o apoiavam desde 1919. Em pouco tempo, propriedades e negócios dos judeus foram apropriados por autoridades do governo. Nesse contexto, Freud foi "visitado" pela Gestapo e teve passaportes, dinheiro, livros e documentos confiscados. Sua filha Anna foi retida por um dia para interrogatório e seu filho Martin foi preso. Assistindo diariamente à transformação de sua cidade num campo de concentração, Freud se convenceu da necessidade imediata de emigrar. O embaixador William Bullit, com o qual Freud tinha colaborado na biografia do presidente Woodrow Wilson, e o secretário de estado Cordell Hull obtiveram, por intermédio do presidente Franklin Roosevelt, proteção internacional para Freud, enquanto Ernest Jones providenciou na Inglaterra o processo de expatriação. Marie Bonaparte, por sua vez, saldou as dívidas da editora de Freud e organizou sua viagem final para Londres. Essa articulação diplomática infelizmente não angariou dinheiro suficiente para comprar o mesmo "benefício" para quatro irmãs de Freud que permaneceram em Viena e foram posteriormente deportadas e mortas em campos de extermínio (Gay, 1989). Ainda pior do que ter assistido a tais fatos, e ter se inteirado das notícias que eram divulgadas pela imprensa internacional e pelas rádios (Gay, 1989), Freud, antes de partir de Viena, foi atravessado pelo holocausto, no temor pelo futuro de seus parentes e pelo seu próprio e também como vítima como todos os judeus o foram em maior ou menor grau.

5 Pogroms é um termo em iídiche que define a perseguição genocida sofrida pelos judeus em diferentes momentos de sua história.

6 “[...] nem as mais cruéis perseguições conseguiram arrefecê-los, mostraram, ao contrário, aptidão para se fortalecerem para ganharem seu sustento e, em todas as vezes que lhes é permitido, contribuem de forma valiosa em todos os êxitos culturais" (Freud, 1939/2004, p. 88).

7 “Os motivos mais profundos do ódio ao judeu se estabelecem em épocas do passado remoto, produzem seus efeitos desde o inconsciente dos povos, e estou preparado para que não pareçam críveis à primeira vista” (Freud, 1939/2004, p. 88).

8 Ieshivot (plural), ieshivá (singular): Escolas de estudo destinadas a jovens estudantes do sexo masculino, cujo currículo se dedica à Halachá (literalmente "modo de andar", mais especificamente as leis ditadas pelos rabinos a partir de raciocínios e discussões sobre as passagens da Bíblia), as leis contidas em seções do Talmud (traduz-se por estudo mas aqui nos referimos à sua definição como Torá Oral: um compêndio de tratados sobre leis e comportamentos para os judeus, constituídos por comentários rabínicos dispostos à margem da página em cujo centro figura uma determinada passagem da Bíblia que se pretendia debater e elucidar). "As ieshivot se originaram das academias da Palestina e da Babilônia, nos primeiros séculos da era cristã. [...] o estudo se faz aos pares com a análise do texto talmúdico, e há uma aula diária (shiur) dada por um dirigente da ieshivá (rosh ieshivá)" (Unterman, A., 1992, p. 122).

9 Intelectualidade, espiritualidade.

10 Sensorialidade, percepção pelos sentidos.

11 “[...] de Sellin tomamos a suposição de que o Moisés egípcio foi assassinado pelos judeus, que abandonaram a religião que ele introduziu" (Freud, 1939/2004, p. 36).

12 Um dos historiadores atraídos por tal ideia a exemplo de Breasted, (1934 citado em Freud, 1939/2004, p. 9); Rank, (1909 citado em Freud, 1939/2004, p. 13).

13 Tanach é um termo que tem como tradução para o português A Bíblia hebraica, englobando 24 livros: os 5 livros de Moisés (o Pentateuco) 8 livros dos primeiros e últimos profetas e 11 livros hagiógrafos (Unterman, A., 1992, p. 262; Goldberg \& Rayner, 1986) 
14 Espírito, intelecto, tempo, ou época.

15 As mitsvot são as obrigações (mandamentos) positivas e negativas observadas em escalas diferentes por comunidades liberais, ortodoxas e ultra-ortodoxas. "Lembrai-vos da Lei de Moisés, Meu servo, a quem ordenei, em Horeb, estatutos e leis para todo o Israel" (Malaquias 3:22).

16 Palavra em hebraico que se traduz por Nomes, mas o termo escolhido para a tradução em português é Êxodo.

17 "Era bom", "ki tov": expressão empregada em Bereshit (Gênesis) na criação da luz e se refere, de acordo com o Tal$m u d$, ao fato de Moisés já ter nascido circuncidado "indicando [nele] um elevado grau de perfeição" (p. 155). Desde o nascimento, Moisés, um humano concebido por dois levitas, já demonstrava sua excepcionalidade pois a circuncisão é uma prática cirúrgica ritual feita após o nascimento. Não se tem notícia de outro personagem judaico que tenha nascido sem o prepúcio, nem mesmo Abraão, o patriarca do pacto com Deus, cuja lembrança é reintroduzida, e renovada com a circuncisão dos filhos homens.

18 (em hebraico transliterado Adonai echad, isto é, D’us é único, só existe um D'us).

19 A ideia, o conceito no lugar do referente, por exemplo, a ideia de árvore e não a árvore real (Saussure, 1917 citado em Chemama, 2009).

* Artigo iniciado durante a vigência da bolsa de doutorado da Capes e finalizado durante a vigência da bolsa nota 10 de doutorado da Faperj (Fundação Carlos Chagas de Ensino e Pesquisa). 